\title{
Financial Soundness Indicator, Financial Cycle, Credit Cycle and Business Cycle-Evidence from Taiwan
}

\author{
Yuan Chang ${ }^{1}$ \\ ${ }^{1}$ Department of Finance, National ChangHua University of Education, ChangHua, Taiwan (R.O.C) \\ Correspondence: Yuan Chang, Department of Finance, National ChangHua University of Education, No. 2, \\ Shi-Da Road, Changhua City, Taiwan (R.O.C). Tel: 886-4723-2105-7350. E-mail: ychang@cc.ncue.edu.tw
}

Received: January 4, 2016

Accepted: January 25, 2016

Online Published: March 25, 2016

doi:10.5539/ijef.v8n4p166

URL: http://dx.doi.org/10.5539/ijef.v8n4p166

\begin{abstract}
Business cycle is the repeated expansions (from trough to peak) and contractions (from peak to trough) of real economic activity. Credit cycle is the cyclical process of the bank credit, ranging from short/long-term, loan to enterprise and loan to individual. Financial cycle reflects ups and downs in asset prices and financial institution's balance sheet. This paper examines the linkage among cycles as well as their lead-lag relationship. Theoretically, credit cycle is one of reasons driving business cycle, and financial cycle is a fundamental cause of credit cycle. Based on Taiwan's quarterly data, this paper firstly identifies cyclical behavior of indicators of real economic activity, bank credit and assets prices in recent decade by defining expansion phases and contraction phases of cyclical variables. Second, this paper calculates concordance index to examine the degree of synchronization among cycles. Third, while the soundness for assets and liabilities of financial institution may drive financial cycle, this paper employs IMF's Financial Soundness Indicator (FSI) as predictor of expansion and contraction phase of cyclical variables. Specifically, the paper assesses the health of bank's balance sheet variables by Probit estimation on linkage between FSIs and expansion/contraction phase of cycle. Based on empirical evidence, the knowledge about the extent of assets/liability condition of financial institution corresponding to the expansion and contraction phase of financial, credit and business cycle is enhanced. Authority concerning about financial stability should oversight the performance of FSIs and then engage in prompt corrective actions when the level and volatility of those indicators sharply.
\end{abstract}

Keywords: financial soundness indicator, financial cycle, credit cycle, business cycle

\section{Introduction}

Business cycle refers to cyclical behavior (boom and bust) of real economic activities (such as consumption, investment and total production) and nominal economic variables (such as price level). This phenomenon is driven by real factors (productivity), monetary and monetary/fiscal policy factors, expectations (including consumer and business confidence), international factors and their interaction. Existing studies such as Keynes (1936), Galbraith (1954) and Shiller (1989) emphasized that the fluctuation in economic and financial activity is mainly due to the "animal spirits", emphasizing the irrational behavior on interpreting ups and downs of living standard. Other researchers think that some economic expectations that are not realized constitutes the driving force of fluctuation of the economy (DeLong, 1992; Siegel, 1998; Edwards, Biscarri, \& Perez de Gracia, 2003).

Recent view has indicated that cyclical behavior of real economy activity is caused by fluctuation in credit amount. As credit amount experiences its expansion status, loanable fund supply is sufficient to finance borrowing demand by investment, consumption, and then real GDP is fostered. Conversely, as credit amount enters into its contraction status, loan supply is retrenched and real economic activity is then cooled. The phenomenon of credit amount fluctuation is generally viewed as credit cycle. Minsky $(1977,1992)$ proposed financial instability hypothesis and indicated that financial instability reflecting on expansion/contraction of credit is a driving force of business cycle. In credit expansion phase, the level of interest rate is very low such that the borrower can easily obtain fund from financial institutions (FIs) and FIs will be willing to lend because the expansion of economic activity is expected to get a cash flow growth and thus the borrower has sufficient resource to repay. This process encourages corporate investment and household consumption and thus fosters excessive borrowing, yet the default risk of the borrower is then inflated. As the borrower's default reaches a significant level, the lenders are reluctant to supply loan, thus the contraction of the credit amount may lead to 
contraction of investment, consumption and other real activities. Therefore, credit cycle is a source of business cycle and this proposition is supported by Eckstein and Sinai (1986) and Summers (1986).

Fisher (1933) proposed debt-deflation theory, indicating that declining in asset price reduces net worth of people and firm such that consumer spending and corporate investment are contracted, thereby enabling the overall contraction of economic activity and price level is also screw down. Bernanke and Gertler (1989) believed that the decline in asset price deteriorates net worth of individual/firm, then expenditures, investment and economic activity shrinks which in turn makes asset prices further decline. Mishkin (2001) proposed that the fluctuation in asset prices, for examples, stock market price, real estate price and exchange rate cause fluctuation in investment and overall economic activity. While aforementioned study did not point out the lead-lag relationship between cycles of asset prices and real economic activities, this paper examines whether the fluctuation in asset prices affects the ups and downs of real economic activities.

Bernanke (1993), Boivin, Kiley, and Mishkin (2010) emphasized the importance of credit supply by FIs. They argued that the asset-liability condition of FIs involves the availability of credit. Bank's liquidity and financial soundness affects its ability to meet the funding needs, thereby influencing the boom and bust of real economic activity. As financial soundness of banking system is healthy, normal liquidity and loan supply support sustained growth of real activity. On the contrary, deterioration of financial soundness limits the ability of loanable fund supply by banking system and therefore tighten the vitality of real economic activity. Based on this consideration, recent global development on financial prudential supervision paradigm on financial institutions has gradually adjusted from micro-prudential to macro-prudential supervision (Note 1).

This paper proposes that credit cycle severs as one cause of business cycle, and the source of credit cycle is determined by soundness of financial system. Change in asset price has influence on bank's balance sheet and bank loan supply. As asset price decreases, financial health deteriorates and loan supply is reduced. When asset price rises, financial health amplified, and availability of bank loan increases. Adrian, Moench, and Shin (2009) confirmed that when U.S. securities brokers and dealers' leverage is higher and the higher growth rate of shadow banking assets, bank's return on assets tends to be greater. Ho (2011) indicated that financial disequilibrium is defined as too-fast growth on credit and asset prices and excessively expanding on balance sheet of FIs. Extremely growth on credit and asset price growth follows greater probability of financial crisis. Borio and Lowe (2002) found that credit gap (growth rate is higher than the average growth rate), share price gap, exchange rate gap and output gap have significantly predicting ability on prosperity phases as well as financial distress over three to five years. Trichet (2010) mentioned that the leverage, liquidity and asset price of FIs tend to depart from normal level before financial crisis.

To sum up, business cycle is the variability of real economic activity. The cyclical behavior from expansion and contraction of credit amount is the credit cycle. The ups and downs of asset price and expansion/shrinking of balance sheet scale of FIs is called financial cycle. Borio et al. (2001), Danielsson et al. (2004), Kashyap and Stein (2004), Brunnermeier et al. (2009), Adrian and Shin (2010) have addressed that interaction among cycles may amplify economic fluctuations and possibly lead to serious financial distress and economic dislocations. This paper examines the linkage among cycles based on Taiwan's data. Asset price is proxied by real estate price, credit amount and share price. Health of FIs is proxied by 12 financial soundness indicators (FSIs) proposed by IMF. Probit estimation of regression relating 12 FSIs and different phases (expansion/contraction) of various cycles is also executed.

This paper tries to improve the understanding of which FSI is significantly and relatively associated with expansion/contraction phase of financial cycle. Government policy aiming at financial stability should take care of excessive rise or fall of key FSIs on financial institutions to prevent from large fluctuation on financial/credit cycle, and in turn business cycle. Prompt correction actions are proposed as large swing of FSIs is presented. Next section describes cyclical variables, FSIs, data collection and econometric method. The third section is empirical result. The fourth section concludes.

\section{Variable, Data and Econometric Method}

\subsection{Variable and Data}

\subsubsection{Asset Price and Credit-Real Estate Price, Stock Price and Bank Credit}

Existing studies have discussed the cyclical behavior of asset price. Borio and Lowe (2002) defined asset price prosperity (asset price boom) as the deviation from its own upward growth trend. Detken and Smets (2004) and Adalid and Detken (2007) classified asset price boom/bust as its growth rate exceeds long-term trend by $10 \%$. Igan and Loungani (2009) analyzed the regional housing price of UK, U.S., Dutch and other developed countries, 
and found that in the long run, population as well as construction cost is main determinants of housing price. Changes in market structure and regulation are short-term factors. Cunningham and Kolet (2007) and Hall, McDermott and Tremewan (2006) found that the duration and amplitude of real estate price cycle are not identical across countries and time period.

Mendoza and Terrones (2008) found that the frequency of credit boom is very high, and credit growth is usually accompanied by prosperity of economic output, consumption and investment. As real output is in expansion phase, credit amount tends to be higher over its growth trend. When real output is in contraction phase, credit amount is lower than its growth trend. Similar study is referred to Gourinchas, Valdes, and Landerretche (2001).

Edwards, Biscarri, and Gracia (2003) found that stock price cycle is getting more synchronized (concordance) among different countries and financial markets. Terrones (2004) found that real estate price cycles are also synchronized among countries. Common factors are average interest rate around the world, output level of United States and world commodity prices. Phylaktis and Ravazzolo (2005) found that overall stock price of developed economy and emerging markets are all affected by exchange rate. Similar studies are referred to Gourinchas and Rey (2007) and Caballero, Farhi and Gourinchas (2008). Allen and Gale (2007) pointed out the correlation between financial cycle and financial crisis. When economic activity enjoys a long time warm, credit amount expands, asset price is inflated and currency is overvalued. These situations are then followed by a financial crisis. Reinhart and Rogoff (2009) found significant increase in real estate price and huge credit expansion are usually followed by a banking crisis.

\subsubsection{IMF's Financial Soundness Indicators (FSIs)}

Financial system instability affects the functioning of financial market/intermediate and in turn real economic activity such as consumption and investment. When financial crisis occurs, market order and investor's confidence is loss and recovery period is usually very long on the history. To strengthen the financial system stability, the International Monetary Fund (IMF) and the World Bank promoted the Financial Sector Assessment Program (FSAP) in 1999, provided a complete set of financial stability analysis framework to assist government with identifying the performance and weakness of financial system and potential economy instability. The program ensures stable financial sector development and assists government to develop appropriate policy and measure of financial health. Financial Soundness Indicators (FSIs) are assessments of soundness of financial institution, overall financial market, real estate market, and financial risk of corporate/household sector. Main purpose of FSIs is to monitor overall risk and vulnerability of financial system.

The total number of FSIs is 39. According to the importance and information availability, indicators are divided into 2 sets, namely, Core Set and the Encouraged Set. Core Set consists of 12 core indicators to inspect financial stability of depository institutions. The data is easy to obtain and can be universally applicable to all countries. Encouraged Set consists of 27 indicators to inspect financial stability of depository institution, other financial institutions, non-financial corporate sector, household sector, market liquidity and real estate market. Because comprehensive information availability for the latter is relatively difficult in Taiwan, this paper only incorporates 12 indictors of Core Set into analysis.

Twelve indicators of Core Set are, (1) $C A R$, regulatory capital to risk-weighted asset, (2) CAR1, regulatory tier-1 capital to risk-weighted asset, (3) NPLEQU, nonperforming loan net of provision to capital, (4) $N P L$, nonperforming loan to gross loan, (5) COVERAGE, loan loss provision to nonperforming loan, (6) OBSLOAN, loan-in observation to total loan (original indicator is sectoral lending divided by total loan, yet the paper changes it as OBSLOAN due to data unavailability), (7) ROA, return on asset, (8) ROE, return on equity, (9) NETINT, interest margin to gross income, (10) NONINT, noninterest expense to gross income, (11) LIQASSET, liquid asset to total asset, (12) $L I Q$, liquid asset to short-term liability. The definition and mnemonics of 12 indicators are summarized in Table 2. 
Table 1. IMF's Financial Soundness Indicators (FSIs)

\begin{tabular}{|c|c|}
\hline & Core Set \\
\hline \multicolumn{2}{|l|}{ Deposit-takers } \\
\hline \multirow[t]{6}{*}{ (Capital adequacy)(*) } & $\cdot C A R$ \\
\hline & Regulatory capital to risk-weighted assets \\
\hline & - $C A R 1$ \\
\hline & Regulatory Tier 1 capital to risk-weighted assets \\
\hline & $\cdot N P L E Q U$ \\
\hline & Nonperforming loans net of provisions to capital \\
\hline \multirow[t]{6}{*}{ (Asset quality)(*) } & $\cdot N P L$ \\
\hline & Nonperforming loans to total gross loans \\
\hline & $\cdot$ COVERAGE \\
\hline & Loan Loss Provision to Nonperforming loans \\
\hline & $\cdot$ OBSLOAN \\
\hline & Loans in observation to total loans \\
\hline \multirow[t]{8}{*}{ (Earnings and profitability)(*) } & $\cdot R O A$ \\
\hline & Return on assets \\
\hline & $\cdot \operatorname{ROE}$ \\
\hline & Return on equity \\
\hline & $\cdot$ NETINT \\
\hline & Interest margin to gross income \\
\hline & $\cdot$ NONINT \\
\hline & Noninterest expenses to gross income \\
\hline \multirow[t]{4}{*}{ (Liquidity)(*) } & $\cdot$ LIQASSET \\
\hline & Liquid assets to total assets \\
\hline & $\cdot L I Q$ \\
\hline & Liquid assets to short-term liabilities \\
\hline \multirow[t]{2}{*}{ (Sensitivity to market risk) } & - Net open position in foreign exchange to capital \\
\hline & $\begin{array}{c}\text { Encouraged Set } \\
\end{array}$ \\
\hline \multirow[t]{13}{*}{ Deposit-takers } & Capital to assets \\
\hline & $\cdot$ Large Exposures to capital \\
\hline & - Geographical distribution of loans to total loans \\
\hline & - Gross asset position in financial derivatives to capital \\
\hline & - Gross liability position in financial derivatives to capital \\
\hline & Trading income to total income \\
\hline & - Personnel expenses to noninterest expenses \\
\hline & - Spread between reference lending and deposit rates \\
\hline & -Spread between highest and lowest interbank rate \\
\hline & Customer deposits to total (non-interbank) loans \\
\hline & ·Foreign-currency-denominated loans to total loans \\
\hline & -Foreign-currency-denominated liabilities to total liabilities \\
\hline & - Net open position in equities to capital \\
\hline \multirow[t]{2}{*}{ (Other financial corporations) } & - Assets to total financial system assets \\
\hline & - Assets to GDP \\
\hline (Nonfinancial corporations & - Total debt to equity \\
\hline \multirow[t]{4}{*}{ sector) } & $\cdot$ Return on equity \\
\hline & - Earnings to interest and principal expenses \\
\hline & - Net foreign exchange exposure to equity \\
\hline & - Number of applications for protection from creditors \\
\hline \multirow[t]{2}{*}{ (Households) } & $\cdot$ Household debt to GDP \\
\hline & $\cdot$ Household debt service and principal payments to income \\
\hline \multirow[t]{2}{*}{ (Market liquidity) } & - Average bid-ask spread in the securities market \\
\hline & - Average daily turnover ratio in the securities market \\
\hline \multirow[t]{3}{*}{ (Real estate markets) } & $\cdot$ Real estate prices \\
\hline & - Residential real estate loans to total loans \\
\hline & - Commercial real estate loans to total loans \\
\hline
\end{tabular}

Note. Compilation Guide on Financial Soundness Indicators, IMF, July 30, 2004.

(https://www.imf.org/external/np/sta/fsi/eng/2004/guide/index.htm). 


\subsubsection{Data}

This paper collects individual financial data of all public banks (both domestic and foreign) and then averages them to obtain aggregate soundness indicators of banking sector in Taiwan. All Financial data and macro data such as asset prices and bank credit amount are collected from Taiwan Economic Journal (TEJ). The data frequency is quarterly and ranged from 2001Q1 2013Q4.

\subsection{Peak, Trough, Expansion, Contraction and Concordance Index}

Existing literature addressing identifying cyclical behavior variable is well-documented such as Burns and Mitchell (1946), Stock and Watson (1999), Harding and Pagan (2002a) and Backus and Kehoe (1992). This paper refers to Claessens, Kose and Terrones (2010) to identify cyclical characteristics (peak, trough, expansion phase and contraction phase) of financial variable as well as concordance between/among cycles.

It is intuitive in identifying peak and trough of a cyclical variable. If a variable $f_{t}$ is on its peak, then the level at time $t$ should be greater than of $t+j$ and $t-j$, that is, $\left(f_{t}-f_{t-j}\right)>0$ and $\left(f_{t}-f_{t+j}\right)>0$, where the value of $j$ depends on researcher's decision and data frequency (in this paper, $j=2$ ).

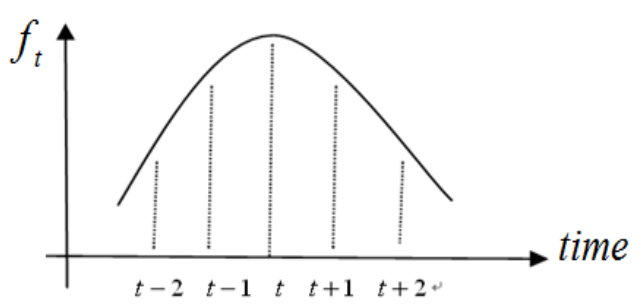

Similarly, if a variable $f_{t}$ is on its trough, the level at time $t$ should be smaller than of $t+j, t-j$, that is, $\left(f_{t}-f_{t-j}\right)<0$ and $\left(f_{t}-f_{t+j}\right)<0$.

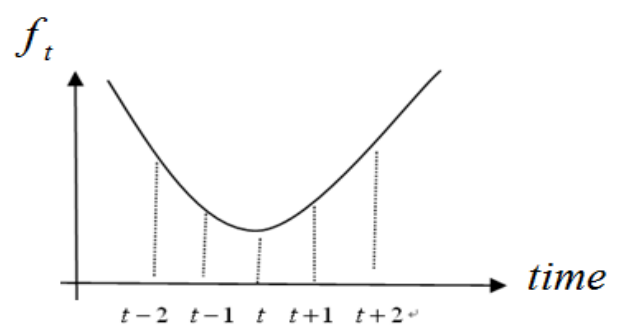

A complete cycle consists of two phases: One is contraction phase, which is defined as a cyclical variable starts with its peak until trough. The other is the expansion phase, which is defined as a cyclical variable starts with its trough toward peak. While sometimes as peak and trough are very far from each other, four-quarter period before a trough could be seen as a contraction phase and four-quarter period before a peak can be viewed as an expansion phase. Expansion phase sometimes called recovery phase, which refers to the early stage (four or six quarters) of the expansion phase (Sichel, 1994). If cyclical variable is a financial one, recovery phase is also named as financial upturn, and contraction phase is called financial downturn.

It is interesting to evaluate whether expansion/contraction phase a cyclical variable is also on expansion/contraction phase of another variable, or vice versa. Harding and Pagan (2002b) and Claessens, Kose and Terrones (2011) introduced Concordance Index (CI) to measure of co-movement between two cycles. The CI is calculated as:

$$
C I_{X y}=\frac{1}{T} \sum_{t=1}^{T}\left[C_{t}^{x} \cdot C_{t}^{y}+\left(1-C_{t}^{X}\right)\left(1-C_{t}^{y}\right)\right]
$$

where $C^{x}{ }_{t}=1$ if variable $x_{t}$ is in expansion phase, and $C^{x}{ }_{t}=0$ as $x_{t}$ is in contraction phase. If variable $y_{t}$ is in expansion (contraction) phase, $C^{y}{ }_{t}=1(0)$. Because a variable at time $\mathrm{t}$ is in either expansion phase or contraction phase but not both, CI measures the proportion of two sequences that are in the same phase. If index is equal to 1 , meaning that two variables are perfectly pro-cyclical, because as $x$ is on its expansion phase and $y$ is always too. If index is equal to 0 , two variables are perfectly counter-cyclical, because as $x$ is on its expansion phase and $y$ is always on contraction phase. Greater CI implies higher synchronization between cycles. 
This paper identifies cyclical behavior of 18 variables. The first four are real estate price, proxied by Shin-Yi Real Estate Price Index of Taipei City (REALTPE), Shin-Yi Real Estate Price Index of Taiwan (REALTWN), consumer price index (CPI) of housing price (REALCPI) and CPI of housing rent (RENTCPI). Stock market price is proxied by weighted average index of the Taiwan Stock Exchange (STOCK) and quarterly change for weighted average index of the Taiwan Stock Exchange (DSTOCK). Bank credit is measured by total bank credit $(L O A N)$, change in total bank credit (DLOAN), short-term loan (STLOAN), long-term loan (LTLOAN), total loan to public/private enterprise (BUSLOAN), change in total loan to public/private enterprise (DBUSLOAN), loan to individual (INDLOAN) and change in loan to individual (DINDLOAN). Real economic activity (business cycle) is measured by gross domestic product $(G D P)$, change in gross domestic product $(D G D P)$, retailed sales index (RETAIL) and industrial production index (IPI).

Based on Claessens, Kose, and Terrones (2011), this paper identifies peaks and troughs of each 18 cyclical variables as well as expansion phases and contraction phases for all variables. Two dummy variables are constructed to indicate a given cyclical variable is lying on expansion or contraction phase. For example, a dummy variable representing expansion phase of REALTPE, namely, EXPREALTPE, is equal to 1 if given point of time REALTPE is on its expansion phase and 0 otherwise. CONREALTPE is equal to 1 if given point of time REALTPE is on its contraction phase and 0 otherwise. It is worth noting that EXPREALTPE plus CONREALTPE is not bounded to 1 , because at some point of time, REALTPE is neither on expansion nor contraction phase. Similarly, 34 dummies representing binary description of expansion/contraction phase of remaining 17 cyclical variables are constructed, which are summarized in Table 2. Constructing these dummies facilitates analyzing concordance between/among cycles as well as examining how FSIs are correlated with expansion/contraction of cyclical variables such as asset price and bank credit.

Table 2. Mnemonics and definition of variables

\begin{tabular}{|c|c|}
\hline Variable/Mnemonics & Definition \\
\hline \multicolumn{2}{|c|}{ Financial Cycle Variable } \\
\hline REALTPE & Shin-Yi Real Estate Price Index of Taipei City \\
\hline REALTWN & Shin-Yi Real Estate Price Index of Taiwan as a whole \\
\hline REALCPI & CPI of housing price \\
\hline RENTCPI & CPI of housing rent \\
\hline STOCK & weighted average index of the Taiwan Stock Exchange \\
\hline DSTOCK & quarterly change for weighted average index of the Taiwan Stock Exchange \\
\hline$L O A N$ & total bank credit \\
\hline$D L O A N$ & change in total bank credit \\
\hline STLOAN & total short-term loan \\
\hline$L T L O A N$ & total long-term loan \\
\hline BUSLOAN & total loan to public/private enterprise \\
\hline DBUSLOAN & change in total loan to public/private enterprise \\
\hline INDLOAN & loan to individual \\
\hline DINDLOAN & change in loan to individual \\
\hline$G D P$ & gross domestic product \\
\hline$D G D P$ & change in gross domestic product \\
\hline RETAIL & retailed sales index \\
\hline$I P I$ & industrial production index \\
\hline \multicolumn{2}{|c|}{ Dummies of Expansion Phase } \\
\hline EXPREALTPE & dummy variable for expansion phase of Shin-Yi Real Estate Price Index of Taipei City \\
\hline EXPREALTWN & dummy variable for expansion phase of Shin-Yi Real Estate Price Index of Taiwan as a whole \\
\hline EXPREALCPI & dummy variable for expansion phase of CPI of housing price \\
\hline EXPRENTCPI & dummy variable for expansion phase of CPI of housing rent \\
\hline EXPSTOCK & dummy variable for expansion phase of weighted average index of the Taiwan Stock Exchange \\
\hline EXPDSTOCK & $\begin{array}{l}\text { dummy variable for expansion phase of quarterly change for weighted average index of the Taiwan } \\
\text { Stock Exchange }\end{array}$ \\
\hline EXPLOAN & dummy variable for expansion phase of total bank credit \\
\hline EXPDLOAN & dummy variable for expansion phase of change in total bank credit \\
\hline EXPSTLOAN & dummy variable for expansion phase of Total short-term loan \\
\hline EXPLTLOAN & dummy variable for expansion phase of Total long-term loan \\
\hline
\end{tabular}




\begin{tabular}{|c|c|}
\hline EXPBUSLOAN & Dummy variable for expansion phase of total loan to public/private enterprise \\
\hline EXPDBUSLOAN & dummy variable for expansion phase of change in total loan to public/private enterprise \\
\hline EXPINDLOAN & dummy variable for expansion phase of loan to individual \\
\hline EXPDINDLOAN & dummy variable for expansion phase of change in loan to individual \\
\hline EXPGDP & dummy variable for expansion phase of gross domestic product \\
\hline EXPDGDP & dummy variable for expansion phase of change in gross domestic product \\
\hline EXPRETAIL & dummy variable for expansion phase of retailed sales index \\
\hline EXPIPI & dummy variable for expansion phase of industrial production index \\
\hline \multicolumn{2}{|c|}{ Dummies of Contraction Phase } \\
\hline CONREALTPE & dummy variable for contraction phase of Shin-Yi Real Estate Price Index of Taipei City \\
\hline CONREALTWN & dummy variable for contraction phase of Shin-Yi Real Estate Price Index of Taiwan as a whole \\
\hline CONREALCPI & dummy variable for contraction phase of CPI of housing price \\
\hline CONRENTCPI & dummy variable for contraction phase of CPI of housing rent \\
\hline CONSTOCK & dummy variable for contraction phase of weighted average index of the Taiwan Stock Exchange \\
\hline CONDSTOCK & $\begin{array}{l}\text { dummy variable for contraction phase of quarterly change for weighted average index of the } \\
\text { Taiwan Stock Exchange }\end{array}$ \\
\hline CONLOAN & dummy variable for contraction phase of total bank credit \\
\hline CONDLOAN & dummy variable for contraction phase of change in total bank credit \\
\hline CONSTLOAN & dummy variable for contraction phase of Total short-term loan \\
\hline CONLTLOAN & dummy variable for contraction phase of Total long-term loan \\
\hline CONBUSLOAN & dummy variable for contraction phase of total loan to public/private enterprise \\
\hline CONDBUSLOAN & dummy variable for contraction phase of change in total loan to public/private enterprise \\
\hline CONINDLOAN & dummy variable for contraction phase of loan to individual \\
\hline CONDINDLOAN & dummy variable for contraction phase of change in loan to individual \\
\hline CONGDP & dummy variable for contraction phase of gross domestic product \\
\hline CONDGDP & dummy variable for contraction phase of change in gross domestic product \\
\hline CONRETAIL & dummy variable for contraction phase of retailed sales index \\
\hline CONTIPI & dummy variable for contraction phase of industrial production index \\
\hline \multicolumn{2}{|c|}{ Financial Soundness Indicators } \\
\hline CAR & regulatory capital to risk-weighted assets \\
\hline CARl & regulatory Tier 1 capital to risk-weighted assets \\
\hline$N P L E Q U$ & nonperforming loans net of provisions to capital \\
\hline$N P L$ & nonperforming loans to total gross loans \\
\hline COVERAGE & loan loss provision to nonperforming loans \\
\hline OBSLAON & loans in observation to total loans \\
\hline$R O A$ & return on assets \\
\hline$R O E$ & return on equity \\
\hline NETINT & interest margin to gross income \\
\hline NONINT & noninterest expenses to gross income \\
\hline LIQASSET & liquid assets to total assets \\
\hline$L I Q$ & liquid assets to short-term liabilities \\
\hline
\end{tabular}

Note. Definitions of variables are from the Taiwan Economic Journal (TEJ) and http://www.sinyi.com.tw/news/article.php/3422.

\subsection{Predicting Cycle Phase by FSIs}

This paper employs 12 FSIs to examine how FSIs are associated with expansion/contraction phase of cyclical variable by regression analysis. While predicted variable is binary or dummy, Probit estimation is executed. Regression equations are as followed:

$$
\begin{aligned}
& \text { Probability }\left(\text { expansion phase } \mathrm{t}_{\mathrm{t}}=1\right)=\mathrm{F}\left(\mathrm{FSIs}_{\mathrm{t}}\right)+\mathrm{U}_{\mathrm{t}} \\
& \text { Probability }\left(\text { contraction phase } \mathrm{t}_{\mathrm{t}}=1\right)=\mathrm{G}\left(\mathrm{FSIs}_{\mathrm{t}}\right)+\mathrm{V}_{\mathrm{t}}
\end{aligned}
$$

While 36 dummies representing dichotomous classification of expansion and contraction phase of cyclical variable, 12 FSIs serve as main explanatory variable for each regression simultaneously may drive multicollinearity problem, thus this paper employ simple regression such that each regression equation incorporates only one FSI at a time. Thus, for a given predicted variable, 12 regressions with single explanatory variable (FSI) are estimated. 


\section{Empirical Results}

\subsection{Concordance between Cyclical Variables}

Table 3 reports descriptive statistics. It is worth noted that we did not successfully identify any peak or trough for total bank long-term loan $(L T L O A N)$, therefore it has no expansion or contraction phase and dummies for proxying its expansion phase (EXPLTLOAN) and contraction phase (CONLTLOAN) are both equal to zero.

Table 4 reports pair-wise Concordance Index (Claessens, Kose, \& Terrones, 2011) among cyclical variables. Several phases of cyclical variables have great concordance (pro-cyclical). For example, Shin-Yi Real Estate Price Index of Taiwan (2: REALTWN), has high concordance with (5: STOCK), (6: DSTOCK), (9: STLOAN), (12: DBUSLOAN), (15: GDP), (16: DGDP) and (18:IPI), means that real estate price has tendency of positive co-movement with stock market price, short-term loan, loan to business, GDP and industrial production. The explanation is quite intuitive. As the performance of stock market increases, house and company tends to engage in financial versus physical investment, thus why short-term loan and change in loan to business increase as well. Increase in real estate price also as wealth effect on aggregate demand to induce corporate sector to increase its industrial production. GDP is then forstered as well.

It is also interesting that (9: STLOAN), (12: DBUSLOAN) and (14: DINDLOAN) have relatively greater concordance with real estate price and GDP, means that short-term loan, change in loan to business and change in loan to individual have greater positive co-movement with real estate price and economic activity. Based on the evidence of concordance between cycles, large swing in loan may correspond to volatile real estate price and economic activity, more specifically, sharpely increase in loan may attractive government's attention that real estate price and GDP are increase as well.

Table 5 reports Granger causality test result among main cyclical variables (REALTWN, STOCK, LOAN, GDP, RETAIL and IPI) and 12 FSIs. In Table 5, YES means that one variable is Granger caused by other variable at 5\% level of statistical significance, and NO means otherwise (does not reach statistical significance). Starting from the first column, we observe that real estate price $(R E A L T W N)$ is caused by stock price $(S T O C K)$ and retail sales index $(R E T A I L)$. Total loan amount $(L O A N)$ is caused by real estate price $(R E A L T W N)$ and three real activity indicators (GDP, RETAIL and IPI). GDP is caused by real estate price (REALTWN) and total loan amount $(L O A N)$. Other two real activity indicators are caused by asset prices-real estate price (REALTWN) and stock price index $(S T O C K)$. Above evidence shows that stock price drives real estate price, and real estate price drives supply of loan and real economic activities. However, there is a relative little evidence shows that FSIs lead financial cyclical variables, exceptions are total loan is Granger caused by net interest income, GDP is Granger caused by ROA of overall FIs and industrial production is Granger caused by non-interest income.

The brief explanation of the evidence of Granger causality test is that stock price is the most exogenous variable that lead to change in other variables such as real estate price, GDP and industry production. Real estate price is then lead to change in loan amount and three real economic activity indiccators. Change in stock market performance has wealth effect on household and also increase corporate investment (by Tobin's Q Theory) and then lead to increase in real estate price and loan amount. Increase in loan amount facilitates household purchasing demand and corporate production which in turns lead to increase in gross domestic product.

Table 3. Descriptive statistics of variables

\begin{tabular}{lccccc}
\hline Variable & \# of Obs. & Mean & Std. Dev. & Minimum & Maximum \\
\hline REALTPE & 52 & 171.7083 & 65.15603 & 93.48 & 304.85 \\
REALTWN & 52 & 161.4615 & 55.73601 & 96.39 & 286.53 \\
REALCPI & 40 & 98.53203 & 2.194357 & 95.15 & 102.8 \\
RENTCPI & 40 & 99.69598 & 0.7723364 & 98.757 & 101.547 \\
STOCK & 40 & 7283.209 & 1126.265 & 4640.79 & 9248.64 \\
DSTOCK & 40 & 7.404165 & 23.01741 & -47.38 & 68.27 \\
LOAN & 40 & $1.75 \mathrm{E}+07$ & 1991536 & $1.37 \mathrm{E}+07$ & $2.09 \mathrm{E}+07$ \\
DLOAN & 40 & 4.80641 & 3.160835 & -1.19 & 10.2733 \\
STLOAN & 40 & 4344524 & 401744 & 3844297 & 5141656 \\
LTLOAN & 40 & $1.32 \mathrm{E}+07$ & 1634086 & 9815326 & $1.57 \mathrm{E}+07$ \\
BUSLOAN & 40 & 7693954 & 1195381 & 5662155 & 9596011 \\
DBUSLOAN & 40 & 5.781672 & 4.297383 & -5.94 & 11.9233 \\
INDLOAN & 40 & 8088183 & 923034.6 & 5963670 & 9758435 \\
\hline
\end{tabular}




\begin{tabular}{|c|c|c|c|c|c|}
\hline DINDLOAN & 40 & 5.871087 & 5.233949 & -0.7533 & 17.4267 \\
\hline$G D P$ & 41 & 3319928 & 392143.8 & 2610574 & 4065702 \\
\hline$D G D P$ & 41 & 1.002439 & 1.847077 & -5.07 & 4.94 \\
\hline RETAIL & 41 & 103.1554 & 6.413548 & 94.2 & 118.5633 \\
\hline$I P I$ & 41 & 86.48203 & 11.97073 & 60.83 & 103.3367 \\
\hline EXPREALTPE & 48 & 0.208333 & 0.410414 & 0 & 1 \\
\hline EXPREALTWN & 48 & 0.145833 & 0.356674 & 0 & 1 \\
\hline EXPREALCPI & 48 & 0.625 & 0.489246 & 0 & 1 \\
\hline EXPRENTCPI & 36 & 0.138889 & 0.350736 & 0 & 1 \\
\hline EXPSTOCK & 36 & 0.361111 & 0.487136 & 0 & 1 \\
\hline EXPDSTOCK & 36 & 0.361111 & 0.487136 & 0 & 1 \\
\hline EXPLOAN & 36 & 0.138889 & 0.350736 & 0 & 1 \\
\hline EXPDLOAN & 36 & 0.305556 & 0.467177 & 0 & 1 \\
\hline EXPSTLOAN & 36 & 0.472222 & 0.506309 & 0 & 1 \\
\hline EXPLTLOAN & 36 & 0 & 0 & 0 & 0 \\
\hline EXPBUSLOAN & 36 & 0.277778 & 0.454257 & 0 & 1 \\
\hline EXPDBUSLOAN & 36 & 0.444444 & 0.503953 & 0 & 1 \\
\hline EXPINDLOAN & 36 & 0.138889 & 0.350736 & 0 & 1 \\
\hline EXPDINDLOAN & 36 & 0.305556 & 0.467177 & 0 & 1 \\
\hline$E X P G D P$ & 37 & 0.72973 & 0.450225 & 0 & 1 \\
\hline EXPDGDP & 37 & 0.621622 & 0.491672 & 0 & 1 \\
\hline EXPRETAIL & 37 & 0.540541 & 0.505228 & 0 & 1 \\
\hline EXPIPI & 37 & 0.27027 & 0.450225 & 0 & 1 \\
\hline CONREALTPE & 48 & 0.1875 & 0.394443 & 0 & 1 \\
\hline CONREALTWN & 48 & 0.229167 & 0.424744 & 0 & 1 \\
\hline CONREALCPI & 47 & 0.085106 & 0.282057 & 0 & 1 \\
\hline CONRENTCPI & 36 & 0.166667 & 0.377965 & 0 & 1 \\
\hline CONSTOCK & 36 & 0.277778 & 0.454257 & 0 & 1 \\
\hline CONDSTOCK & 36 & 0.527778 & 0.506309 & 0 & 1 \\
\hline CONLOAN & 36 & 0.055556 & 0.232311 & 0 & 1 \\
\hline CONDLOAN & 36 & 0.444444 & 0.503953 & 0 & 1 \\
\hline CONSTLOAN & 36 & 0.361111 & 0.487136 & 0 & 1 \\
\hline CONLTLOAN & 36 & 0 & 0 & 0 & 0 \\
\hline CONBUSLOAN & 36 & 0.083333 & 0.280306 & 0 & 1 \\
\hline CONDBUSLOAN & 36 & 0.472222 & 0.506309 & 0 & 1 \\
\hline CONINDLOAN & 36 & 0.055556 & 0.232311 & 0 & 1 \\
\hline CONDINDLOAN & 36 & 0.416667 & 0.5 & 0 & 1 \\
\hline CONGDP & 37 & 0.243243 & 0.434959 & 0 & 1 \\
\hline CONDGDP & 37 & 0.324324 & 0.474579 & 0 & 1 \\
\hline CONRETAIL & 37 & 0.405405 & 0.497743 & 0 & 1 \\
\hline CONIPI & 37 & 0.594595 & 0.497743 & 0 & 1 \\
\hline$C A R$ & 34 & 12.81338 & 3.257955 & 7.203704 & 29.04982 \\
\hline CAR1 & 34 & 10.90084 & 1.672664 & 7.001951 & 17.15447 \\
\hline$N P L E Q U$ & 30 & 5.682404 & 4.974982 & 0.991423 & 16.11609 \\
\hline$N P L$ & 30 & 1.383192 & 1.011114 & 0.2738095 & 3.608182 \\
\hline COVERAGE & 30 & 620.4417 & 805.5106 & 58.60378 & 3702.831 \\
\hline OBSLAON & 52 & 1.489835 & 2.046119 & 0.066 & 8.22 \\
\hline$R O A$ & 52 & 0.0294189 & 0.3608627 & -1.158529 & 0.6228205 \\
\hline$R O E$ & 52 & -0.3771376 & 3.673233 & -11.07528 & 4.836191 \\
\hline NETINT & 52 & 40.95886 & 5.270763 & 24.31732 & 48.22419 \\
\hline NONINT & 52 & 91.67275 & 19.04282 & 67.14107 & 158.2795 \\
\hline LIQASSET & 52 & 24.27527 & 5.530987 & 17.10206 & 35.00658 \\
\hline$L I Q$ & 52 & 193.6334 & 63.12004 & 113.2125 & 317.3385 \\
\hline
\end{tabular}

Note. This table reports basic descriptive statistics (mean, standard deviation, minimum and maximum) of variables. See Table 2 for the definition of variables. Quarterly data is ranged from 2001Q1 to 2013Q4. 
Table 4. Concordance index among cycles

\begin{tabular}{|c|c|c|c|c|c|c|c|c|c|c|c|c|c|c|c|c|c|c|}
\hline \multirow{2}{*}{ Variable } & \multicolumn{4}{|c|}{ Real Estate Price } & \multicolumn{2}{|c|}{ Stock Price } & \multicolumn{2}{|c|}{ Credit } & \multirow[b]{2}{*}{ (9) } & \multirow[b]{2}{*}{ (10) } & \multirow[b]{2}{*}{ (11) } & \multirow[b]{2}{*}{ (12) } & \multirow[b]{2}{*}{ (13) } & \multicolumn{5}{|c|}{ Economic Activity } \\
\hline & (1) & (2) & (3) & (4) & (5) & (6) & (7) & (8) & & & & & & (14) & (15) & (16) & (17) & (18) \\
\hline (1) & 1.0000 & & & & & & & & & & & & & & & & & \\
\hline (2) & 0.3056 & 1.0000 & & & & & & & & & & & & & & & & \\
\hline (3) & 0.2222 & 0.2222 & 1.0000 & & & & & & & & & & & & & & & \\
\hline (4) & 0.0833 & 0.0833 & 0.2222 & 1.0000 & & & & & & & & & & & & & & \\
\hline (5) & 0.1944 & 0.1944 & 0.3056 & 0.0833 & 1.0000 & & & & & & & & & & & & & \\
\hline (6) & 0.1667 & 0.1667 & 0.3611 & 0.0833 & 0.5278 & 1.0000 & & & & & & & & & & & & \\
\hline (7) & 0.0556 & 0.0556 & 0.1389 & 0.1667 & 0.0000 & 0.0000 & 1.0000 & & & & & & & & & & & \\
\hline (8) & 0.0556 & 0.0556 & 0.2778 & 0.1667 & 0.1667 & 0.2500 & 0.1389 & 1.0000 & & & & & & & & & & \\
\hline (9) & 0.2500 & 0.2500 & 0.4722 & 0.1944 & 0.3056 & 0.4167 & 0.1389 & 0.2778 & 1.0000 & & & & & & & & & \\
\hline (10) & 0.0000 & 0.0000 & 0.0000 & 0.0000 & 0.0000 & 0.0000 & 0.0000 & 0.0000 & 0.0000 & 1.0000 & & & & & & & & \\
\hline (11) & 0.0556 & 0.0556 & 0.2500 & 0.1944 & 0.0833 & 0.0556 & 0.1944 & 0.2222 & 0.2500 & 0.0000 & 1.0000 & & & & & & & \\
\hline (12) & 0.1667 & 0.1667 & 0.4167 & 0.1944 & 0.1944 & 0.2500 & 0.1667 & 0.4722 & 0.6111 & 0.0000 & 0.3056 & 1.0000 & & & & & & \\
\hline (13) & 0.0833 & 0.0833 & 0.1944 & 0.1944 & 0.0556 & 0.0556 & 0.1389 & 0.1111 & 0.1389 & 0.0000 & 0.1389 & 0.1111 & 1.0000 & & & & & \\
\hline (14) & 0.1111 & 0.1111 & 0.3333 & 0.1111 & 0.3056 & 0.4444 & 0.0556 & 0.4167 & 0.3333 & 0.0000 & 0.1111 & 0.2778 & 0.0833 & 1.0000 & & & & \\
\hline (15) & 0.1667 & 0.1667 & 0.6944 & 0.1667 & 0.3333 & 0.4167 & 0.1111 & 0.3889 & 0.4722 & 0.0000 & 0.2222 & 0.4167 & 0.1667 & 0.3333 & 1.0000 & & & \\
\hline (16) & 0.1944 & 0.1944 & 0.5556 & 0.0833 & 0.5556 & 0.5833 & 0.0000 & 0.3056 & 0.3889 & 0.0000 & 0.0556 & 0.2222 & 0.0556 & 0.4722 & 0.6111 & 1.0000 & & \\
\hline (17) & 0.0833 & 0.0833 & 0.4167 & 0.0833 & 0.3611 & 0.4167 & 0.0556 & 0.3889 & 0.3056 & 0.0000 & 0.1389 & 0.3056 & 0.0556 & 0.3889 & 0.6389 & 0.6389 & 1.0000 & \\
\hline (18) & 0.1944 & 0.1944 & 0.3056 & 0.1111 & 0.3333 & 0.0000 & 0.0556 & 0.3889 & 0.4722 & 0.0000 & 0.1389 & 0.5278 & 0.0833 & 0.3611 & 0.4722 & 0.4444 & 0.4167 & 1.0000 \\
\hline
\end{tabular}

Note. This table reports pair-wise concordance index (Claessens, Kose and Terrones, 2011) among variables. See Table 2 for the definition of variables. Quarterly data, ranged from 2004Q3 to 2013Q2. Large concordance index represents two cycles are more pro-cyclical. Cyclical variables are named (1) (18), which are (1) Shin-Yi Real Estate Price Index of Taipei City, REALTPE (2) Shin-Yi Real Estate Price Index of Taiwan as a whole, REALTWN (3) CPI of housing price, REALCPI (4) CPI of housing rent, RENTCPI (5) weighted average index of the Taiwan Stock Exchange, STOCK (6) quarterly change for weighted average index of the Taiwan Stock Exchange, DSTOCK (7) total bank credit, LOAN (8) change in total bank credit, DLOAN (9) Total short-term loan, STLOAN (10) Total long-term loan, LTLOAN (11) total loan to public/private enterprise, BUSLOAN (12) change in total loan to public/private enterprise, DBUSLOAN (13) loan to individual, INDLOAN (14) change in loan to individual, DINDLOAN (15) gross domestic product, GDP (16) change in gross domestic product, $D G D P$ (17) retailed sales index, RETAIL (18) industrial production index, IPI.

To examine the exogeneity of variables, we employ four cyclical variables, namely, real estate price (REALTWN), stock price $(S T O C K)$, loan amount $(L O A N)$ and real economic activity $(G D P)$ to estimate vector autoregressive (VAR) model with 4-period lag and then perform forecast error variance decompositions (VDCs) analysis. In Figure 1, we observe that stock price explains the greatest portion of forecast error variance of real estate price. Loan amount explains the second largest portion of forecast error variance of GDP. This means that stock price is main factor explaining real estate price and loan is also the driving factor on explaining real economic activities, supports the view that asset price drives credit supply and in turns leads to real economic fluctuation.

\subsection{How FSIs Predict Expansion/Contraction Phase}

Table 6 reports pair-wise Pearson correlation coefficients among expansion phases of main cyclical variables (EXPREALTWN, EXPSTOCK, EXPLOAN, EXPGDP, EXPDGDP, EXPRETAIL and EXPIPI) and 12 FSIs. First, correlation coefficients on EXPREALTWN and CAR, ROA, ROE, NETINT and LIQ are significantly negative, means that when real estate price is on expansion phase, bank's capital adequacy ratio, profitability ratio and liquidity ratio are deteriorated. Correlation coefficients on EXPREALTWN and NPLEQU and NPL are significantly positive, means that when real estate price is on expansion phase, bank's asset quality is deteriorated. Second, correlation coefficients on EXPSTOCK and NPLEQU and LIQ are significantly positive 
Table 5. Granger causality test among cyclical variables and FSIs

\begin{tabular}{|c|c|c|c|c|c|c|}
\hline Variable & REALTWN & STOCK & $L O A N$ & $G D P$ & RETAIL & $I P I$ \\
\hline REALTWN & - & $\mathrm{NO}$ & YES & YES & YES & YES \\
\hline STOCK & YES & - & NO & YES & $\mathrm{NO}$ & YES \\
\hline$L O A N$ & NO & NO & - & NO & NO & $\mathrm{NO}$ \\
\hline$G D P$ & NO & NO & YES & - & YES & YES \\
\hline RETAIL & YES & $\mathrm{NO}$ & YES & YES & - & YES \\
\hline$I P I$ & NO & NO & YES & YES & YES & - \\
\hline$C A R$ & NO & NO & NO & NO & NO & NO \\
\hline CAR1 & $\mathrm{NO}$ & $\mathrm{NO}$ & $\mathrm{NO}$ & NO & NO & NO \\
\hline$N P L E Q U$ & NO & NO & $\mathrm{NO}$ & NO & NO & NO \\
\hline$N P L$ & NO & NO & $\mathrm{NO}$ & NO & NO & NO \\
\hline COVERAGE & $\mathrm{NO}$ & NO & $\mathrm{NO}$ & NO & NO & NO \\
\hline OBSLAON & NO & NO & $\mathrm{NO}$ & NO & NO & $\mathrm{NO}$ \\
\hline$R O A$ & NO & NO & $\mathrm{NO}$ & YES & NO & YES \\
\hline$R O E$ & NO & NO & NO & NO & NO & $\mathrm{NO}$ \\
\hline NETINT & NO & NO & YES & NO & NO & $\mathrm{NO}$ \\
\hline NONINT & $\mathrm{NO}$ & NO & NO & YES & YES & YES \\
\hline LIQASSET & NO & $\mathrm{NO}$ & $\mathrm{NO}$ & NO & NO & NO \\
\hline$L I Q$ & NO & $\mathrm{NO}$ & NO & $\mathrm{NO}$ & $\mathrm{NO}$ & $\mathrm{NO}$ \\
\hline
\end{tabular}

Note. This table reports Granger causality tests among main cyclical variables and 12 FSIs. YES means that row variable is Granger caused by column variable at 5\% level of statistical significance, and NO means otherwise. See Table 2 for the definition of variables. Quarterly data is ranged from 2001Q1 to 2013Q4.

V ariance Decomposition of RE ALTW N

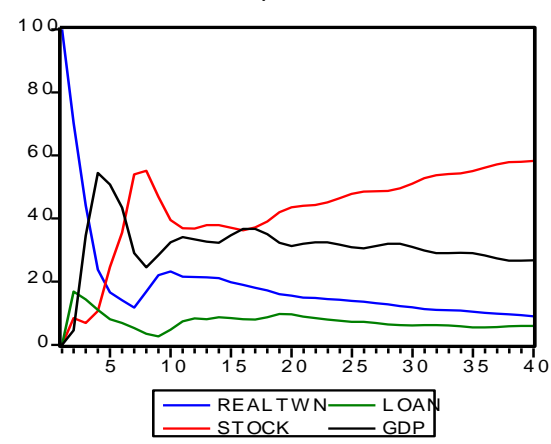

V ariance Decomposition of LOAN

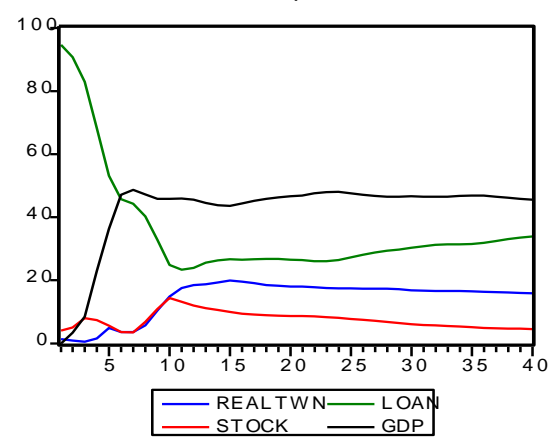

V ariance Decomposition of S TOCK

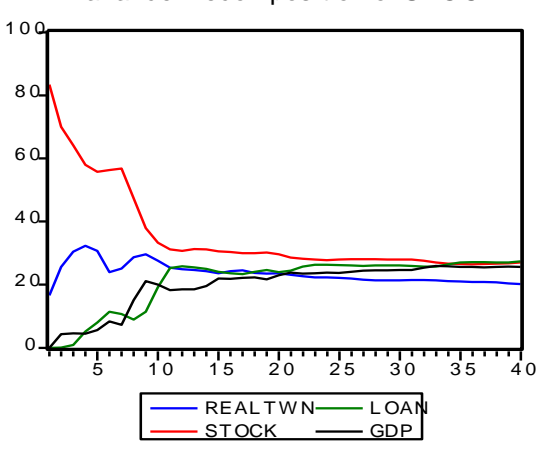

V ariance Decomposition of GDP

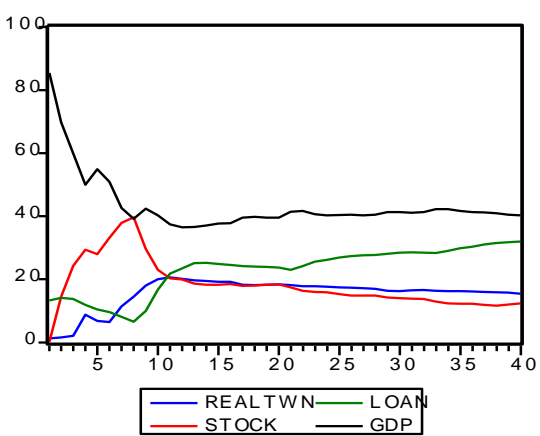

Figure 1. Forecast error variance decompostion analysis 
Table 6. Pair-wise pearson correlation coefficient among FSIs and expansion phase of cyclical variables

\begin{tabular}{|c|c|c|c|c|c|c|c|c|c|c|c|c|c|c|c|c|c|c|c|}
\hline & (1) & (2) & (3) & (4) & (5) & (6) & (7) & (8) & (9) & (10) & (11) & (12) & (13) & (14) & (15) & (16) & (17) & (18) & (19) \\
\hline (1)EXPREALTWN & 1.0000 & & & & & & & & & & & & & & & & & & \\
\hline (2)ЕХРSTOCK & 0.2151 & 1.0000 & & & & & & & & & & & & & & & & & \\
\hline (3)EXPLOAN & 0.2086 & -0.3019 & 1.0000 & & & & & & & & & & & & & & & & \\
\hline (4)EXPGDP & -0.0168 & 0.0789 & -0.1096 & 1.0000 & & & & & & & & & & & & & & & \\
\hline (5)EXPDGDP & -0.0500 & $0.4448^{*}$ & $-0.5342^{*}$ & 0.1526 & 1.0000 & & & & & & & & & & & & & & \\
\hline (6)EXPRETAIL & -0.2470 & 0.2069 & -0.1257 & 0.2937 & $0.3989^{*}$ & 1.0000 & & & & & & & & & & & & & \\
\hline (7)EXPIPI & 0.1722 & 0.1793 & -0.0697 & 0.2333 & 0.0984 & -0.0495 & 1.0000 & & & & & & & & & & & & \\
\hline (8)CAR & $-0.4194 *$ & -0.2705 & -0.1055 & 0.1261 & 0.0987 & -0.0458 & 0.0124 & 1.0000 & & & & & & & & & & & \\
\hline (9)CARI & -0.2604 & -0.2585 & -0.1116 & 0.1701 & 0.0062 & 0.0393 & 0.0856 & $0.8078^{*}$ & 1.0000 & & & & & & & & & & \\
\hline (10)NPLEQU & $0.7605^{*}$ & $0.3916^{*}$ & 0.0780 & 0.1027 & 0.1450 & -0.0637 & -0.0660 & $-0.7847^{*}$ & -0.2988 & 1.0000 & & & & & & & & & \\
\hline (11)NPL & $0.7379 *$ & 0.2961 & 0.2443 & 0.1302 & 0.0161 & -0.0763 & -0.1634 & $-0.7120^{*}$ & -0.1694 & $0.9093^{*}$ & 1.0000 & & & & & & & & \\
\hline (12)COVERAGE & -0.3632 & 0.0807 & -0.1709 & 0.2109 & 0.2466 & 0.2643 & 0.3565 & $0.4197^{*}$ & 0.1706 & $-0.4309^{*}$ & $-0.4769^{*}$ & 1.0000 & & & & & & & \\
\hline (13)OBSLAON & -0.1558 & -0.1073 & -0.0115 & 0.0953 & -0.1896 & -0.2449 & -0.2713 & -0.0461 & 0.1478 & $0.9429 *$ & $0.8933^{*}$ & $-0.4855^{*}$ & 1.0000 & & & & & & \\
\hline (14)ROA & $-0.4547 *$ & -0.2955 & -0.1790 & -0.1027 & -0.0820 & -0.0873 & 0.2085 & $0.3597^{*}$ & 0.1180 & $-0.7510^{*}$ & $-0.7619^{*}$ & $0.3624^{*}$ & -0.0481 & 1.0000 & & & & & \\
\hline (15)ROE & $-0.4821^{*}$ & -0.1808 & -0.1217 & -0.1432 & -0.0013 & -0.1584 & -0.0289 & 0.2370 & -0.1434 & $-0.7884^{*}$ & $-0.7650^{*}$ & $0.3853^{*}$ & -0.1578 & $0.7339^{*}$ & 1.0000 & & & & \\
\hline (16)NETINT & $-0.4927^{*}$ & -0.2922 & $-0.4649 *$ & 0.1576 & 0.0308 & 0.0746 & 0.2053 & $0.4772^{*}$ & $0.3940^{*}$ & $-0.7593^{*}$ & $-0.7929 *$ & $0.4268^{*}$ & $-0.5168^{*}$ & $0.3821^{*}$ & $0.3569^{*}$ & 1.0000 & & & \\
\hline (17)NONINT & 0.2610 & 0.1941 & 0.2482 & 0.1733 & 0.0679 & 0.2532 & -0.2667 & -0.1827 & 0.1189 & $0.7413^{*}$ & $0.7958^{*}$ & -0.3454 & $0.3115^{*}$ & $-0.7195^{*}$ & $-0.7802^{*}$ & $-0.3020^{*}$ & 1.0000 & & \\
\hline (18)LIQASSET & -0.2481 & -0.2681 & -0.1078 & 0.1101 & 0.1044 & -0.0509 & $-0.3937^{*}$ & $0.5313^{*}$ & $0.5153^{*}$ & 0.4954* & $0.6352^{*}$ & -0.2723 & $0.5247^{*}$ & 0.0467 & -0.0030 & 0.0341 & $0.2927^{*}$ & 1.0000 & \\
\hline (19)LIQ & $-0.4392^{*}$ & $-0.3408^{*}$ & -0.3081 & 0.0663 & 0.1679 & -0.0065 & -0.2560 & $0.6745^{*}$ & $0.4267^{*}$ & $-0.8495^{*}$ & $-0.8446^{*}$ & $0.4193^{*}$ & $0.8059^{*}$ & 0.1454 & 0.1131 & -0.0842 & 0.2076 & $0.7868^{*}$ & 1.0000 \\
\hline
\end{tabular}

Note. This table reports pair-wise Pearson correlation coefficients among expansion phases of cyclical variables and financial soundness indicators. See Table 1 for the definition of variables. Quarterly data is employed. Correlation coefficient followed by an asterisk means that it is at least $10 \%$ significantly different from zero.

and negative, respectively, means that when stock market price is on expansion phase, bank's asset quality and liquidity condition become weaker. Third, correlation coefficient of EXPLOAN and NETINT is significantly negative, means that when total bank loan is on expansion phase, bank's net interest margin is deteriorated.

Table 7 reports pair-wise Pearson correlation coefficients among contraction phase of main cyclical variables and FSIs. Correlation coefficients of CONREALTWN and OBSLOAN and NONINT are significantly positive (0.5572 and 0.4169), means that as real estate price is on contraction phase, bank's asset quality is deteriorated yet noninterest income is increased. Correlation coefficients of CONREALTWN and ROA, NETINT are significantly negative, mean that as real estate price is on contraction phase, bank's profitability and net interest margin is deteriorated.

Table 8 reports simple Probit estimation on the relationship between expansion phase of cyclical variable and 12 FSIs. When predicted variable is EXPREALTWN, estimated coefficients on NPLEQU, NPL and NONINT are positive and significant $(0.257,3.3933$ and 0.0353$)$, means that bank's asset quality tends to decrease as real estate price is on expansion phase. Bank's noninterest income tend to increase as real estate price is on expansion phase. When predicted variable is EXPREALTWN, coefficients on CAR, COVERAGE, ROA, ROE and NETINT are significantly negative, means that bank's capital adequacy, asset quality, profitability and net interest margin are deteriorated as real estate price is on expansion phase.

Table 9 reports simple Probit estimation on the relationship between contraction phase of cyclical variable and 12 FSIs. When explained variable is CONREALTPE, coefficients of OBSLOAN and NETINT are significantly positive and negative (0.2646 and -0.0904), respectively, represents that bank's asset quality and net interest margin are deteriorated as real estate price in Taipei is on contraction phase.

In summary, empirical evidence generally shows that stock market performance is the most exogenous variable that may drive change in other variables such as real estate price. Increase in real estate price is concordance with increase in loan amount and other real activities. Banking supervisors may also take greater care of large movement in short term loan and growth rate of loan to business and loan to individual. It is more important that FSIs did good prediction about expansion versus contraction phases of real estate price. As a rule of thumb, while banking soundness worsened during contraction phase of real estate price, bank health indeed deteriorated even during expansion phase. Thus, government should always watch FSIs to prevent from banking fragility due to over lending on real estate sector as stock market performance is booming and real estate price is climbing. 


\section{Conclusion}

Business cycle is the repeated expansion and contraction of real economic activity. Credit cycle is cyclical process of bank credit. Financial cycle is ups and downs in asset price and financial institutions' balance sheet. This paper examines the linkage among cycles and tests whether FSIs act as good predictor for expansion /contraction phase of cyclical variable. Based on Taiwan's aggregate data during recent decade, firstly, the paper identifies cyclical behavior of financial cycle, credit cycle and business cycle and defines expansion and contraction phases for them. Then, we calculate concordance index between cycles. Third, employ IMF's FSIs as predictor of expansion and contraction phase of cyclical variables by Probit regression estimation.

The main finding shows that short-term credit, changed level in loan to business and changed loan to individual have higher concordance with other cyclical variable such as real estate price index and real economic activities. The evidence implies that in addition to stock market boom, banking supervisors should also pay attention on large swing in short term loan and growth rate of loan to business and loan to individual. Besides, several FSIs such as bank's profitability ratio, asset quality ratio, capital adequacy ratio and liquidity ratio act as predictor for expansion/contraction phases of real estate price. On average, banking soundness worsened during contraction phase as well as expansion phase of real estate price. Thus, ups and downs of real estate price should be monitored by banking supervisors to prevent from banking fragility.

This paper helps us to obtain basic knowledge about how to identify cyclical behavior of financial versus real economic activity indicators, whether cyclical variables are co-movement as well as countercyclical and how the assets-liability condition of financial institutions change over expansion/contraction phase of financial cyclical variables. The authority should take care of soundness of financial system over different phase of financial versus credit cycle and engage in prompt corrective action as key soundness indicators, asset prive and bank credit amount have large fluctuation.

Table 7. Pair-wise pearson correlation coefficient among FSIs and contraction phase of cyclical variables

\begin{tabular}{|c|c|c|c|c|c|c|c|c|c|c|c|c|c|c|c|c|c|c|}
\hline & (1) & (2) & (3) & (4) & (5) & (6) & (7) & $(8)$ & (9) & (10) & (11) & $(12)$ & (13) & $(14)$ & (15) & $(16)$ & (17) & (18) \\
\hline (1) CONREALTWN & 1.0000 & & & & & & & & & & & & & & & & & \\
\hline (2) CONSTOCK & $0.3727^{*}$ & 1.0000 & & & & & & & & & & & & & & & & \\
\hline (3) CONLOAN & -0.0857 & -0.1504 & 1.0000 & & & & & & & & & & & & & & & \\
\hline (4) $C O N G D P$ & 0.0055 & -0.0716 & 0.1400 & 1.0000 & & & & & & & & & & & & & & \\
\hline (5) $C O N D G D P$ & 0.3166 & $0.6657^{*}$ & -0.1609 & 0.1455 & 1.0000 & & & & & & & & & & & & & \\
\hline (6) CONRETAIL & -0.1102 & -0.0210 & -0.2050 & 0.3017 & 0.2511 & 1.0000 & & & & & & & & & & & & \\
\hline (7) CONIPI & 0.2875 & 0.1468 & -0.0410 & $0.3398^{*}$ & $0.3369 *$ & 0.1212 & 1.0000 & & & & & & & & & & & \\
\hline (8) $C A R$ & -0.1226 & -0.0486 & 0.0184 & -0.1224 & -0.0765 & 0.0537 & -0.0270 & 1.0000 & & & & & & & & & & \\
\hline (9) $C A R I$ & -0.1569 & -0.1124 & 0.0638 & -0.1571 & -0.0419 & -0.0225 & -0.0898 & $0.8078^{*}$ & 1.0000 & & & & & & & & & \\
\hline (10) NPLEQU & 0.2163 & -0.1342 & -0.0126 & -0.0280 & -0.1972 & 0.1346 & 0.2091 & $-0.7847 *$ & -0.2988 & 1.0000 & & & & & & & & \\
\hline (11) $N P L$ & 0.2330 & -0.0068 & 0.1272 & -0.0503 & -0.1016 & 0.1530 & 0.1788 & $-0.7120^{*}$ & -0.1694 & $0.9093^{*}$ & 1.0000 & & & & & & & \\
\hline (12) COVERAGE & -0.1513 & -0.1886 & -0.1373 & -0.2386 & -0.2239 & -0.2845 & -0.3208 & $0.4197 *$ & 0.1706 & $-0.4309^{*}$ & $-0.4769 *$ & 1.0000 & & & & & & \\
\hline (13) OBSLAON & $0.5572^{*}$ & 0.0522 & -0.1104 & -0.0450 & 0.2020 & 0.1197 & $0.4413^{*}$ & -0.0461 & 0.1478 & $0.9429^{*}$ & $0.8933^{*}$ & $-0.4855^{*}$ & 1.0000 & & & & & \\
\hline (14) $R O A$ & $-0.3075^{*}$ & 0.0485 & -0.0049 & 0.0543 & 0.0853 & 0.0511 & -0.2881 & $0.3597 *$ & 0.1180 & $-0.7510^{*}$ & $-0.7619^{*}$ & $0.3624 *$ & -0.0481 & 1.0000 & & & & \\
\hline (15) $R O E$ & -0.2776 & 0.0968 & -0.0465 & 0.0966 & 0.1169 & 0.0978 & -0.0530 & 0.2370 & -0.1434 & $-0.7884^{*}$ & $-0.7650^{*}$ & $0.3853^{*}$ & -0.1578 & $0.7339^{*}$ & 1.0000 & & & \\
\hline (16) NETINT & $-0.3459 *$ & -0.0133 & -0.1511 & -0.1546 & -0.0108 & -0.1560 & -0.2221 & $0.4772^{*}$ & $0.3940^{*}$ & $-0.7593^{*}$ & $-0.7929 *$ & $0.4268^{*}$ & $-0.5168^{*}$ & $0.3821^{*}$ & $0.3569^{*}$ & 1.0000 & & \\
\hline (17) NONINT & $0.4169^{*}$ & 0.0004 & 0.1098 & -0.0950 & -0.0469 & -0.1845 & 0.3016 & -0.1827 & 0.1189 & $0.7413^{*}$ & $0.7958^{*}$ & -0.3454 & $0.3115^{*}$ & $-0.7195 *$ & $-0.7802^{*}$ & $-0.3020^{*}$ & 1.0000 & \\
\hline (18) LIQASSET & 0.1840 & -0.1217 & -0.0023 & -0.0895 & -0.0613 & -0.0423 & $0.4352^{*}$ & $0.5313^{*}$ & $0.5153^{*}$ & $0.4954^{*}$ & $0.6352^{*}$ & -0.2723 & $0.5247^{*}$ & 0.0467 & -0.0030 & 0.0341 & $0.2927^{*}$ & 1.0000 \\
\hline
\end{tabular}

Note. This table reports pair-wise Pearson correlation coefficients among contraction phases of cyclical variables and financial soundness indicators. See Table 1 for the definition of variables. Quarterly data is employed. Correlation coefficient followed by an asterisk means that it is at least $10 \%$ significantly different from zero. 
Table 8. Simple probit regression on the relationship between FSIs and expansion phase of cyclical variables

\begin{tabular}{|c|c|c|c|c|c|c|c|c|c|c|c|c|c|c|c|c|c|}
\hline \multirow{3}{*}{$\begin{array}{c}\text { Explanatory } \\
\text { Variable } \\
\text { (FSIs) }\end{array}$} & \multicolumn{17}{|c|}{ Expansion Cycles } \\
\hline & \multicolumn{17}{|c|}{ Explained Variable } \\
\hline & (1) & (2) & (3) & (4) & (5) & (6) & (7) & $(8)$ & $(9)$ & $(10)$ & $(11)$ & $(12)$ & (13) & (14) & (15) & (16) & (17) \\
\hline \multirow{2}{*}{ CAR } & $-1.0628^{* *}$ & -1.0628 & -0.0283 & -0.1895 & -0.2579 & 0.0144 & -0.0900 & -0.0201 & -0.2530 & -0.0161 & -0.0344 & -0.1895 & -0.1770 & 0.0770 & 0.0481 & -0.0171 & 0.0054 \\
\hline & $(-2.54)$ & $(-2.54)$ & $(-0.38)$ & $(-1.17)$ & $(-1.56)$ & $(0.22)$ & $(-0.61)$ & $(-0.25)$ & $(-1.46)$ & $(-0.21)$ & $(-0.45)$ & $(-1.17)$ & $(-1.21)$ & $(0.71)$ & $(0.57)$ & $(-0.25)$ & $(0.07)$ \\
\hline \multirow{2}{*}{ CARI } & -0.2745 & -0.2745 & -0.0729 & -0.3447 & -0.2423 & -0.0762 & -0.1283 & -0.1620 & -0.2070 & -0.1054 & 0.0549 & -0.3447 & $-0.4763^{* * *}$ & 0.1537 & 0.0050 & 0.0281 & 0.0712 \\
\hline & $(-1.42)$ & $(-1.42)$ & $(-0.48)$ & $(-1.53)$ & $(-1.42)$ & $(-0.60)$ & $(-0.67)$ & $(-0.97)$ & $(-1.32)$ & $(-0.68)$ & $(0.41)$ & $(-1.53)$ & $(-2.01)$ & $(0.95)$ & $(0.04)$ & $(0.22)$ & $(0.51)$ \\
\hline \multirow{2}{*}{$N P L E Q U$} & $0.2570^{* * *}$ & $0.2570^{* * * *}$ & 0.1541 & 0.0797 & $0.1120^{* *}$ & $0.0843 *$ & 0.0264 & -0.0114 & 0.0363 & -0.0694 & -0.0072 & 0.0797 & 0.0569 & 0.0290 & 0.0408 & -0.0162 & -0.0174 \\
\hline & $(3.38)$ & $(3.38)$ & (1.56) & $(1.42)$ & $(2.04)$ & $(1.68)$ & $(0.45)$ & $(-0.22)$ & $(0.76)$ & $(-1.20)$ & $(-0.15)$ & (1.42) & (1.15) & $(0.55)$ & $(0.79)$ & $(-0.34)$ & $-(0.35)$ \\
\hline \multirow{2}{*}{$N P L$} & $3.3933^{* * *}$ & $3.3933^{* *}$ & 0.4773 & $0.5322^{*}$ & 0.3843 & $0.4477^{*}$ & 0.4106 & -0.0838 & 0.1465 & -0.2113 & -0.0158 & $0.5322^{*}$ & 0.0836 & 0.1880 & 0.0205 & -0.0946 & -0.2075 \\
\hline & $(2.24)$ & $(2.24)$ & $(1.51)$ & $(1.71)$ & (1.59) & $(1.80)$ & (1.37) & $(-0.33)$ & $(0.62)$ & $(-0.83)$ & $(-0.07)$ & $(1.71)$ & $(0.34)$ & $(0.71)$ & $(0.09)$ & $(-0.40)$ & $(-0.87)$ \\
\hline \multirow{2}{*}{ COVERAGE } & $-0.0088^{* * *}$ & $-0.0088^{* *}$ & -0.0005 & -0.0010 & 0.0001 & $-0.0015^{*}$ & -0.0008 & 0.0005 & 0.0004 & 0.0000 & 0.0002 & -0.0010 & 0.0005 & 0.0007 & 0.0007 & 0.0007 & 0.0007 \\
\hline & $(-2.40)$ & $(-2.40)$ & $(-1.47)$ & $(-0.98)$ & $(0.43)$ & $(-1.68)$ & $(-0.85)$ & (1.46) & (1.15) & $(0.16)$ & $(0.78)$ & $(-0.98)$ & (1.39) & (1.02) & $(1.18)$ & (1.25) & $(1.61)$ \\
\hline \multirow{2}{*}{ OBSLAON } & 0.1727 & -0.2349 & $-0.6254 * * *$ & 0.0958 & -0.4159 & -0.0760 & -0.0598 & 0.3485 & -0.0919 & -1.2308 & 0.4377 & 0.0958 & $1.0718^{*}$ & 0.3430 & -0.5789 & -0.7941 & -1.2779 \\
\hline & (1.54) & $(-1.06)$ & $(-3.00)$ & $(0.13)$ & $(-0.65)$ & $(-0.13)$ & $(-0.08)$ & $(0.59)$ & $(-0.16)$ & $(-1.44)$ & $(0.74)$ & $(0.13)$ & $(1.67)$ & $(0.59)$ & $(-1.12)$ & $(-1.45)$ & $(-1.62)$ \\
\hline \multirow{2}{*}{$R O A$} & $-1.7370^{* * * *}$ & $-1.8430^{* * * *}$ & -0.3436 & -0.4622 & $-1.2623^{*}$ & -1.0976 & -0.8355 & 0.9898 & -1.2598 & 0.1476 & 0.4069 & -0.4622 & 0.2489 & -0.4867 & -0.3629 & -0.3603 & 1.2480 \\
\hline & $(-2.88)$ & $(-2.76)$ & $(-0.67)$ & $(-0.58)$ & $(-1.67)$ & $(-1.49)$ & $(-1.10)$ & $(1.11)$ & $(-1.59)$ & $(0.20)$ & $(0.58)$ & $(-0.58)$ & $(0.35)$ & $(-0.63)$ & $(-0.51)$ & $(-0.53)$ & $(1.27)$ \\
\hline \multirow{2}{*}{$R O E$} & $-0.2069^{* * * *}$ & $-0.1799^{* * *}$ & -0.0386 & -0.0485 & -0.0605 & -0.0089 & -0.0506 & 0.0953 & -0.0402 & 0.0470 & -0.0412 & -0.0485 & 0.1016 & -0.0634 & -0.0004 & -0.0554 & -0.0093 \\
\hline & $(-3.20)$ & $(-2.81)$ & $(-0.74)$ & $(-0.72)$ & $(-1.07)$ & $(-0.16)$ & $(-0.76)$ & (1.24) & $(-0.72)$ & $(0.70)$ & $(-0.73)$ & $(-0.72)$ & (1.31) & $(-0.89)$ & $(-0.01)$ & $(-0.96)$ & $(-0.17)$ \\
\hline \multirow{2}{*}{ NETINT } & $-0.2077^{* * * *}$ & $-0.1866^{* * * *}$ & 0.0178 & $-0.3240 * *$ & $-0.0963^{*}$ & -0.0689 & $-0.2203^{* *}$ & 0.0462 & -0.0608 & -0.0165 & 0.0048 & $-0.3240^{* * *}$ & 0.0537 & 0.0540 & 0.0097 & 0.0233 & 0.0756 \\
\hline & $(-3.64)$ & $(-3.06)$ & $(0.41)$ & $(-2.50)$ & $(-1.72)$ & $(-1.26)$ & $(-2.42)$ & $(0.82)$ & $(-1.11)$ & $(-0.30)$ & $(0.09)$ & $(-2.50)$ & $(0.97)$ & $(0.97)$ & $(0.19)$ & $(0.45)$ & $(1.26)$ \\
\hline \multirow{2}{*}{ NONINT } & $0.0353^{* * *}$ & $0.0204^{*}$ & -0.0113 & 0.0154 & 0.0149 & 0.0112 & 0.0238 & -0.0142 & 0.0115 & -0.0008 & 0.0002 & 0.0154 & -0.0155 & 0.0157 & 0.0055 & 0.0217 & -0.0262 \\
\hline & $(2.85)$ & $(1.80)$ & $(-1.16)$ & $(0.97)$ & $(1.16)$ & $(0.87)$ & (1.49) & $(-0.97)$ & $(0.88)$ & $(-0.06)$ & $(0.02)$ & $(0.97)$ & $(-1.05)$ & (1.05) & $(0.42)$ & (1.53) & $(-1.61)$ \\
\hline \multirow{2}{*}{ LIQASSET } & -0.0273 & -0.1029 & $-0.0694 * *$ & -0.0522 & -0.0983 & 0.0040 & -0.0491 & -0.0011 & -0.0549 & -0.2952 & -0.0025 & -0.0522 & 0.0361 & 0.0318 & 0.0268 & -0.0123 & $-0.5283^{* *}$ \\
\hline & $(-0.70)$ & $(-1.64)$ & $(-2.08)$ & $(-0.71)$ & $(-1.55)$ & $(0.09)$ & $(-0.68)$ & $(-0.03)$ & $(-1.22)$ & $(-1.58)$ & $(-0.06)$ & $(-0.71)$ & $(0.84)$ & $(0.68)$ & $(0.64)$ & $(-0.31)$ & $(-2.52)$ \\
\hline \multirow{2}{*}{$L I Q$} & -0.0020 & $-0.0833^{* * * *}$ & $-0.0150^{* * * *}$ & $-0.0468^{* *}$ & $-0.0163^{* *}$ & -0.0021 & $-0.0318^{*}$ & 0.0001 & -0.0100 & -0.0157 & -0.0032 & -0.0468 & 0.0052 & 0.0025 & 0.0059 & -0.0002 & -0.0122 \\
\hline & $(-0.64)$ & $(-2.62)$ & $(-3.80)$ & $(-2.14)$ & $(-1.97)$ & $(-0.36)$ & $(-1.78)$ & $(0.01)$ & $(-1.61)$ & $(-1.73)$ & $(-0.56)$ & $(-2.14)$ & $(0.87)$ & $(0.41)$ & $(1.02)$ & $(-0.04)$ & $(-1.56)$ \\
\hline
\end{tabular}

Note. This table reports simple Probit estimation results of regression analysis which relate binary description of expansion phases of cyclical variable to 12 financial soundness indicators. 17 explained variables (1) (17) are EXPREALTPE, EXPREALTWN, EXPREALCPI, EXPRENTCPI, EXPSTOCK, EXPDSTOCK, EXPLOAN, EXPDLOAN, EXPSTLOAN, EXPBUSLOAN, EXPDBUSLOAN, EXPINDLOAN, EXPDINDLOAN, EXPGDP, EXPDGDP, EXPRETAIL, EXPIPI, respectively. Quarterly data is employed. See Table 1 for the definition of variables. The $z$-statistics are shown in the parentheses below estimated coefficients, and ${ }^{* * *},{ }^{* *}$ and ${ }^{*}$ denote $1 \%, 5 \%$ and $10 \%$ significantly different from zero.

Table 9. Simple probit regression on the relationship between FSIs and contraction phase of cyclical variables

\begin{tabular}{|c|c|c|c|c|c|c|c|c|c|c|c|c|c|c|c|c|c|}
\hline \multirow{3}{*}{$\begin{array}{c}\text { Explanatory } \\
\text { Variable } \\
\text { (FSIs) }\end{array}$} & \multicolumn{17}{|c|}{ Contraction Cycles } \\
\hline & \multicolumn{17}{|c|}{ Explained Variable } \\
\hline & (1) & $(2)$ & (3) & (4) & $(5)$ & $(6)$ & $(7)$ & $(8)$ & (9) & $(10)$ & $(11)$ & $(12)$ & (13) & $(14)$ & $(15)$ & (16) & $(17)$ \\
\hline \multirow{2}{*}{$C A R$} & -0.1333 & -0.1333 & 0.0383 & 0.0144 & -0.0241 & -0.0175 & 0.0120 & $-0.4300^{* * *}$ & 0.1304 & -0.0045 & 0.0228 & -0.0029 & -0.0542 & -0.0790 & -0.0388 & 0.0197 & -0.0103 \\
\hline & $(-0.79)$ & $(-0.79)$ & $(0.48)$ & $(0.17)$ & $(-0.29)$ & $(-0.25)$ & $(0.11)$ & $(-1.98)$ & $(1.21)$ & $(-0.04)$ & $(0.33)$ & $(-0.02)$ & $(-0.68)$ & $(-0.69)$ & $(-0.45)$ & $(0.29)$ & $(-0.15)$ \\
\hline \multirow{2}{*}{ CARI } & -0.1942 & -0.1942 & 0.1533 & 0.0860 & -0.1059 & 0.1166 & 0.0797 & -0.1262 & 0.2322 & -0.0331 & -0.0477 & 0.0406 & 0.1090 & -0.1420 & -0.0355 & -0.0158 & -0.0671 \\
\hline & $(-0.91)$ & $(-0.91)$ & $(0.91)$ & $(0.54)$ & $(-0.66)$ & $(0.90)$ & $(0.39)$ & $(-0.88)$ & $(1.47)$ & $(-0.16)$ & $(-0.37)$ & $(0.19)$ & $(0.83)$ & $(-0.88)$ & $(-0.24)$ & $(-0.12)$ & $(-0.51)$ \\
\hline \multirow{2}{*}{$N P L E Q U$} & 0.0676 & 0.0676 & -0.0494 & -0.0266 & -0.0420 & -0.0131 & -0.0059 & 0.0826 & 0.0292 & -0.0154 & 0.0418 & -0.0062 & 0.0186 & -0.0079 & -0.0638 & 0.0342 & 0.0545 \\
\hline & $(1.16)$ & (1.16) & $(-0.66)$ & $(-0.41)$ & $(-0.75)$ & $(-0.27)$ & $(-0.07)$ & $(1.60)$ & $(0.60)$ & $(-0.21)$ & $(0.87)$ & $(-0.08)$ & $(0.39)$ & $(-0.15)$ & $(-1.08)$ & $(0.72)$ & $(1.12)$ \\
\hline \multirow{2}{*}{$N P L$} & 0.4118 & 0.4118 & -0.0375 & 0.2399 & -0.0096 & -0.0307 & 0.2751 & $0.4565^{*}$ & 0.0962 & 0.2834 & 0.1788 & 0.2113 & 0.1808 & -0.0734 & -0.1432 & 0.1918 & 0.2259 \\
\hline & $(1.29)$ & (1.29) & $(-0.12)$ & $(0.82)$ & $(-0.04)$ & $(-0.13)$ & $(0.72)$ & $(1.78)$ & $(0.39)$ & $(0.84)$ & $(0.76)$ & $(0.56)$ & $(0.77)$ & $(-0.28)$ & $(-0.56)$ & $(0.81)$ & $(0.96)$ \\
\hline \multirow{2}{*}{ COVERAGE } & -0.0007 & -0.0007 & 0.0004 & -0.0005 & -0.0005 & 0.0003 & -0.0017 & -0.0004 & -0.0009 & -0.0006 & -0.0003 & -0.0016 & -0.0013 & -0.0013 & -0.0007 & -0.0009 & -0.0008 \\
\hline & $(-0.76)$ & $(-0.76)$ & $(1.29)$ & $(-0.73)$ & $(-0.97)$ & $(0.98)$ & $(-0.85)$ & $(-1.08)$ & $(-1.17)$ & $(-0.62)$ & $(-0.86)$ & $(-0.83)$ & $(-1.61)$ & $(-1.25)$ & $(-1.08)$ & $(-1.31)$ & $(-1.45)$ \\
\hline \multirow{2}{*}{ OBSLAON } & $0.2646^{* *}$ & $0.4125^{* * * *}$ & -1.3550 & 0.3235 & 0.1830 & 0.8984 & -1.0341 & -0.2209 & $1.1072^{*}$ & -1.4102 & 0.0250 & -0.3081 & -0.2030 & -0.1601 & 0.6097 & 0.3558 & $2.2659^{* * *}$ \\
\hline & $(2.34)$ & (3.41) & $(-1.11)$ & $(0.51)$ & $(0.30)$ & $(1.37)$ & $(-0.69)$ & $(-0.37)$ & (1.69) & $(-0.97)$ & $(0.04)$ & $(-0.27)$ & $(-0.34)$ & $(-0.28)$ & (1.17) & $(0.73)$ & (2.61) \\
\hline \multirow{2}{*}{$R O A$} & -0.6760 & $-1.0619^{* *}$ & -0.1185 & 0.2205 & 0.2254 & 0.2770 & -0.0361 & $-1.4582^{*}$ & 0.3013 & 0.3316 & -0.8655 & -0.5967 & -1.0244 & 0.2529 & 0.3954 & 0.2110 & $-1.6006^{*}$ \\
\hline & $(-1.26)$ & $(-2.03)$ & $(-0.15)$ & $(0.26)$ & $(0.30)$ & $(0.41)$ & $(-0.03)$ & $(-1.81)$ & $(0.42)$ & $(0.29)$ & $(-1.19)$ & $(-0.62)$ & $(-1.44)$ & $(0.33)$ & $(0.53)$ & $(0.31)$ & $(-1.69)$ \\
\hline \multirow{2}{*}{$R O E$} & -0.0570 & $-0.0968^{*}$ & 0.0254 & 0.0221 & 0.0395 & -0.0495 & -0.0264 & $-0.1362 * *$ & -0.0230 & 0.0048 & 0.0072 & -0.0215 & $-0.1472 * *$ & 0.0421 & 0.0468 & 0.0342 & -0.0175 \\
\hline & $(-1.06)$ & $(-1.90)$ & $(0.32)$ & $(0.30)$ & $(0.60)$ & $(-0.85)$ & $(-0.30)$ & $(-2.01)$ & $(-0.41)$ & $(0.06)$ & $(0.13)$ & $(-0.24)$ & $(-2.14)$ & $(0.61)$ & $(0.73)$ & $(0.60)$ & $(-0.32)$ \\
\hline \multirow{2}{*}{ NETINT } & $-0.0904 *$ & $-0.1129^{* *}$ & 0.0004 & -0.0179 & -0.0043 & 0.0419 & -0.0873 & $-0.1605 * * * *$ & 0.0149 & -0.0892 & -0.0469 & -0.0855 & -0.0391 & -0.0534 & -0.0034 & -0.0496 & -0.0754 \\
\hline & $(-1.82)$ & $(-2.28)$ & $(0.01)$ & $(-0.27)$ & $(-0.08)$ & $(0.78)$ & $(-0.93)$ & $(-2.67)$ & $(0.27)$ & $(-1.08)$ & $(-0.87)$ & $(-0.91)$ & $(-0.73)$ & $(-0.94)$ & $(-0.07)$ & $(-0.94)$ & $(-1.36)$ \\
\hline \multirow{2}{*}{ NONINT } & 0.0141 & $0.0310^{* * * *}$ & 0.0053 & 0.0106 & 0.0000 & 0.0066 & 0.0140 & 0.0143 & 0.0061 & 0.0052 & 0.0116 & 0.0193 & $0.0253^{*}$ & -0.0085 & -0.0039 & -0.0156 & $0.0271^{*}$ \\
\hline & (1.32) & $(2.64)$ & $(0.39)$ & $(0.70)$ & $(0.00)$ & $(0.52)$ & $(0.69)$ & $(1.13)$ & $(0.47)$ & $(0.28)$ & $(0.92)$ & $(0.96)$ & $(1.82)$ & $(-0.59)$ & $(-0.29)$ & $(-1.13)$ & $(1.81)$ \\
\hline \multirow{2}{*}{ LIQASSET } & 0.0309 & 0.0472 & -0.0778 & 0.0365 & -0.0369 & 0.0266 & -0.0012 & -0.0902 & $0.0885^{*}$ & -0.0045 & 0.0239 & -0.0116 & -0.0618 & -0.0261 & -0.0158 & -0.0104 & 0.2293 \\
\hline & $(0.82)$ & $(1.31)$ & $(-1.12)$ & $(0.74)$ & $(-0.74)$ & $(0.61)$ & $(-0.02)$ & $(-1.63)$ & (1.95) & $(-0.07)$ & $(0.56)$ & $(-0.14)$ & $(-1.29)$ & $(-0.56)$ & $(-0.37)$ & $(-0.26)$ & (1.63) \\
\hline \multirow{2}{*}{$L I Q$} & 0.0047 & $0.0078^{* * *}$ & -0.0067 & 0.0041 & -0.0069 & -0.0010 & -0.0015 & $-0.0180^{* * *}$ & 0.0094 & -0.0028 & 0.0032 & -0.0038 & $-0.0143^{* *}$ & -0.0036 & -0.0044 & -0.0036 & 0.0100 \\
\hline & $(1.46)$ & $(2.46)$ & $(-1.07)$ & $(0.60)$ & $(-1.04)$ & $(-0.18)$ & $(-0.15)$ & $(-2.24)$ & $(1.55)$ & $(-0.29)$ & $(0.56)$ & $(-0.34)$ & $(-2.05)$ & $(-0.58)$ & $(-0.74)$ & $(-0.65)$ & $(1.53)$ \\
\hline
\end{tabular}

Note. This table reports simple Probit estimation results of regression analysis which relate binary description of contraction phases of cyclical variable to 12 financial soundness indicators. 17 explained variables (1) (17) are CONREALTPE, CONREALTWN, CONREALCPI, CONRENTCPI, CONSTOCK, CONDSTOCK, CONLOAN, CONDLOAN, CONSTLOAN, CONBUSLOAN, CONDBUSLOAN, CONINDLOAN, CONDINDLOAN, CONGDP, CONDGDP, CONRETAIL and CONIPI, respectively. Quarterly data is employed. See Table 1 for the definition of variables. The $z$-statistics are shown in the parentheses below estimated coefficients, and ${ }^{* * *},{ }^{* *}{ }^{*}$ and ${ }^{*}$ denote $1 \%, 5 \%$ and $10 \%$ significantly different from zero. 


\section{Acknowledgments}

The author would like to thank the anonymous reviewers for helpful and constructive comments that contributed to improving the final version of the paper. All remaining errors are my own.

\section{References}

Adalid, R., \& Detken, C. (2007). Liquidity Shocks and Asset Price Boom/Bust Cycles. Working Paper Series 732, European Central Bank.

Adrian, T., \& Shin, H. (2010). Financial Intermediaries and Monetary Economics. In B. Friedman, \& M. Woodford (Eds.), Handbook of Monetary Economics (Vol. 3, pp. 601-650). Amsterdam: North Holland. http://dx.doi.org/10.1016/b978-0-444-53238-1.00012-0

Adrian, T., \& Shin, H. S. (2009). Prices and Quantities in the Monetary Policy Transmission Mechanism. International Journal of Central Banking, working paper.

Allen, F., \& Gale, D. (2007). Understanding Financial Crises (Clarendon Lect. Finance). Oxford: Oxford Univ. Press.

Backus, D. K., \& Kehoe, P. J. (1992). International Evidence of the Historical Properties of Business Cycles. American Economic Review, 82(4), 864-888.

Bernanke, B. S. (1993). Credit in the Macroeconomy. Federal Reserve Bank of New York, Spring. Quarterly Review, 50-70.

Bernanke, B., \& Gertler, M. (1989). Agency Costs, Net Worth, and Business Fluctuations. American Economic Review, 79, 14-31.

Boivin, J., Kiley, M. T., \& Mishkin, F. S. (2010). How Has the Monetary Transmission Mechanism Evolved over Time? Finance and Economics Discussion Series 2010-26, Board of Governors of the Federal Reserve System (U.S.).

Borio, C., \& Lowe, P. (2002). Asset Prices, Financial and Monetary Stability: Exploring the Nexus. BIS Working Paper, No. 114. http://dx.doi.org/10.2139/ssrn.846305

Borio, C., McCauley, R., \& McGuire, P. (2011). Global Credit and Domestic Credit Booms. BIS Quarterly Review, September, 43-57.

Brunnermeier, M., Crockett, A., Goodhart, C., Hellwig, M., Persaud, A., \& Shin, H. (2009). The Fundamental Principles of Financial Regulation, Geneva Reports on the World Economy, no 11.

Burns, A. F., \& Mitchell, W. C. (1946). Measuring Business Cycles. New York: National Bureau of Economic Research.

Caballero, R. J., Farhi, E., \& Gourinchas, P. O. (2008). Financial Crash, Commodity Prices and Global Imbalances. NBER Working Papers 14521, National Bureau of Economic Research, Inc.

Claessens, M., Kose, A., \& Terrones, M. E. (2010). Financial Cycles: What? How? When? IMF working paper.

Cunningham, R., \& Kolet, I. (2007). Housing Market Cycles and Duration Dependence in the United States and Canada. Working Paper 2007-02, Bank of Canada.

Danielsson, J., Shin, H. S., \& Zigrand, J. P. (2004). The Impact of Risk Regulation on Price Dynamics. Journal of Banking and Finance, 28(5), 1069-1087. http://dx.doi.org/10.1016/S0378-4266(03)00113-4

DeLong, J. B. (1992). Bull and Bear in the US. In P. Newman, M. Milgate, \& J. Eatwell (Eds.), The New Palgrave Dictionary of Money and Finance (pp. 253-255). Mac Millan Press Limited, London.

Detken, C., \& Smets, F. (2004). Asset Price Booms and Monetary Policy. Working Paper Series 364, European Central Bank.

Eckstein, O., \& Sinai, A. (1986). The Mechanisms of the Business Cycle in the Postwar Era. In R. Gordon (Ed.), The American Business Cycle: Continuity and Change. University of Chicago Press for NBER.

Edwards, S., Biscarri, J. G., \& Perez de Gracia, F. (2003). Stock Market Cycles, Financial Liberalization and Volatility. Journal of International Money and Finance, 22, 925-955. http://dx.doi.org/10.1016/j.jimonfin.2003.09.011

Fisher, I. (1933). The Debt-Deflation Theory of Great Depressions. Econometrica, 1, 337-357. http://dx.doi.org/10.2307/1907327 
Flood, R. P., \& Taylor, M. P. (1996). Exchange Rate Economics: What's Wrong with the Conventional Macro Approach? In The Microstructure of Foreign Exchange Markets (pp. 261-302). NBER Chapters, National Bureau of Economic Research, Inc.

Galbraith, J. K. (1954). The Great Crash - 1929. Boston, MA: Houghton Mifflin.

Gourinchas, P. O., \& Hélène, R. (2007). International Financial Adjustment.Journal of Political Economy, 115, 665-703. http://dx.doi.org/10.1086/521966

Gourinchas, P. O., Valdes, R., \& Landerretche, O. (2001). Lending Booms: Latin America and the World. Economia, Spring, 47-99. http://dx.doi.org/10.1353/eco.2001.0004

Hall, V. B., McDermott, C. J., \& Tremewan, J. (2006). The Ups and Downs of New Zealand House Prices. Motu Economic and Public Policy Research. http://dx.doi.org/10.2139/ssrn.923705

Harding, D., \& Pagan, A. (2002a). Dissecting the Cycle: A Methodological Investigation. Journal of Monetary Economics, 49, 365-381. http://dx.doi.org/10.1016/S0304-3932(01)00108-8

Harding, D., \& Pagan, A. (2002b). A Comparison of two Business Cycle Dating Methods. Journal of Economics Dynamics and Control, 27, 1681-1690. http://dx.doi.org/10.1016/S0165-1889(02)00076-3

Ho, D. C. (2011). Factors Influencing Business Cycles. Taiwan Economic Forum, 9(1), 55-82.

Igan, D., \& Loungani, P. (2009). House prices: Global Correction, Local Consequences. Working Paper, IMF.

Kashyap, A., \& Stein, J. (2004). Cyclical Implications of the Basel II Capital Standards. Federal Reserve Bank of Chicago Economic Perspectives, (1), 18-31.

Keynes, J. M. (1936). The General Theory of Employment Interest and Money. In D. E. Moggridge (Ed.), The Collected Writings of John Maynard Keynes (Vol. VII). London: Macmillan.

Mendoza, E., \& Terrones, M. E. (2008). An Anatomy of Credit Booms: Evidence from Macro Aggregates and Micro Data. NBER Working Paper No. 14049. http://dx.doi.org/10.2139/ssrn.1292330

Minsky, H. P. (1977). The Financial Instability Hypothesis: An Interpretation of Keynes and Alternative to Standard Theory. Challenge, March-April, 20-27. http://dx.doi.org/10.1080/05775132.1977.11470296

Minsky, H. P. (1992). The Financial Instability Hypothesis. Working Paper No. 74.

Mishkin, F. S. (2001). The Transmission Mechanism and the Role of Asset Prices in Monetary Policy. NBER Working Paper, No. 8617.

Phylaktis, K., \& Ravazzolo, F. (2005). Stock Prices and Exchange Rate Dynamics. Journal of International Money and Finance, 24(7), 1031-1053. http://dx.doi.org/10.1108/20400701111165623

Reinhart, C., \& Kenneth, R. (2009). This Time Is Different: Eight Centuries of Financial Folly. Princeton University Press.

Shiller, R. J. (1989). Comovements in Stock Prices and Comovements in Dividends. The Journal of Finance, 44, 719-729. http://dx.doi.org/10.2307/2328779

Sichel, D. E. (1994). Inventories and the Three Phase of the Business Cycle. Journal of Business and Economic Statistics, 12(3), 269-277. http://dx.doi.org/10.1080/07350015.1994.10524542

Siegel, J. J. (1998). Stocks for the Long-Run: The Definitive Guide to Financial Market Returns and Long-term Investment Strategies. McGraw-Hill, New York.

Stern, R. M. (1973). The Balance of Payments: Theory and Economic Policy. Chicago: Aldine Publishing Company. http://dx.doi.org/10.1007/978-1-349-01658-7

Stock, J. H., \& Watson, M. W. (1999). Business Cycle Fluctuations in US Macroeconomic Time Series. In J. B. Taylor, \& M. Woodford (Eds.), Handbook of Macroeconomics (Vol. 1). Elsevier Science B.V. http://dx.doi.org/10.1016/s1574-0048(99)01004-6

Summers, L. (1986). Does the Stock Market Rationally Reflect Fundamental Values? The Journal of Finance, 41, 591-601. http://dx.doi.org/10.1111/j.1540-6261.1986.tb04519.xView/save citation

Summers, L. H. (1986). Debt Problems and Macroeconomic Policies. NBER Working Papers 2061, National Bureau of Economic Research.

Terrones, M. (2004). The Global House Price Boom. IMF World Economic Outlook, September, 71-136. http://dx.doi.org/10.1080/02673030802550128 
Trichet J. (2010). What Can Central Banks Do in a Financial Crisis? Speech on the Occasion of the Susan Bies Lecture, Kellogg Distinguished Lecture Series, Evanston, Illinois, 27 April.

\section{Note}

Note 1. According Ho (2011), the Bank for International Settlements (BIS) defined macro-prudential policy as prudential tools that contribute to the stability of financial system as a whole, not necessarily in promoting the stability of individual financial institutions. Macro-prudential tools implemented in Asian countries, in terms of overall risk management of pro-cyclical features, including countercyclical provision of capital and loan loss provision, limiting the number of mortgage lending, and direct control of lending to specific sectors. Overall risk management under every single point in time, including the additional capital on systemically and significantly financial institutions (capital surcharge), liquidity requirements, financing and deposit-loan ratio requirements.

\section{Copyrights}

Copyright for this article is retained by the author(s), with first publication rights granted to the journal.

This is an open-access article distributed under the terms and conditions of the Creative Commons Attribution license (http://creativecommons.org/licenses/by/3.0/). 